\title{
A REVOGAÇÃO OU NÃO DA SEPARAÇÃO JUDICIAL APOS A EMENDA CONSTITUCIONAL № 66 À LUZ DO NOVO CODIGO DE PROCESSO CIVIL E DO CÓDIGO CIVIL
}

\author{
Sabrina Rosa Marangoni ${ }^{1}$ \\ Ana Maria Viola de Sousa² \\ Maurício Martins Alves ${ }^{3}$
}

Resumo: Este artigo tem como escopo analisar a Emenda Constitucional $n^{\circ} 66$ (EC 66/2010), promulgada em 13 de julho de 2010, que trouxe inovações no texto da Constituição Federal alterando o seu artigo 226. Analisa a doutrina existente sobre o tema, parte dela favorável à leitura de rogação tácita, outra parte considerando que o instituto da separação judicial encontra-se vigente no ordenamento jurídico brasileiro, e defende que a EC 66/2010 não revogou tacitamente o instituto da separação judicial. Conclui que a separação judicial não é incompatível com atual Ordenamento Jurídico, podendo, portanto, a separação judicial continuar existindo sem colidir com os outros institutos previstos na legislação vigente no Brasil.

Palavras-chave: Emenda Constitucional n66/2010; Separação judicial; Divórcio; Novo Código de Processo Civil.

\footnotetext{
${ }^{1}$ Direito/Univap, Brasil. E-mail: marangonirsabrina@gmail.com.

2 Direito/Univap, Brasil. E-mail: anaviola@aasp.org.br.

${ }^{3}$ Direito/Univap, Brasil. E-mail: E-mail: mmalves@univap.br.
} 